DOI 10.31558/2307-2318.2021.3.3

УДК 658.012.23

JEL: D46, L20, M11, O32

Безгін К.С.

д.е.н., професор кафедри менеджменту та поведінкової економіки

Донецького національного університету імені Василя Стуса

k.bezghin@donnu.edu.ua

Ушкальов В.В.

к.е.н., доцент кафедри економіки підприємства і організації бізнесу

Харківського національного економічного університету імені Семена Кузнеця

\title{
ЗБОРКА ПОЛІСУБ’ЄКТА СПІЛЬНОГО СТВОРЕННЯ ІННОВАЦІЙНИХ ЦІННОСТЕЙ
}

Фундаментальною передумовою гармонізащії сочіально-економічних прочесів $\epsilon$ розробка та імплементація внутрішньо узгодженої системи поглядів, здатних налаштувати відповідальну інноваџійну діяльність, щуо реалізується на принципах сталого розвитку. Досягнення когнітивних наук та постнекласичного менеджменту засвідчують, щуо суттєвий внесок в формування нової системи поглядів на інноватику може зробити парадигма со-творчості. Мета статті - аналіз та обтрунтування теоретичних і емпіричних основ зборки полісуб'єкта, орієнтованого на співтворчість $i$ розширення когнітивної гетерогенності суб'єктів інноваційного розвитку для активізації інноваційних процесів підприємства та підвищення релевантності створюваних інновачій. В статті розглянуто основні етапи зборки полісуб'єкта спільного створення інновачійних цінностей з їх наповненням в реперних точок індикативними ознаками групової динаміки, щуо фіксують якісні зміни в спільноті. Наведено констеляцію факторів ефективного функціонування полісуб'єктних середовищ спільного створення інноваційних иінностей, які локалізовано за основними етапами зборки. В роботі продемонстровано, щчо полісуб'єкт спільного створення інновацій, здатен генерувати релевантні цінності в тій мірі, в якій він спроможний відтворювати у властивостях створюваних об'єктів основний спектр споживчих конструктів. Передумовою релевантних результатів інновачійної діяльності $є$ сотворчість суб'єктів з високою когнітивною складністю, які у своїй сукупності утворюють когнітивно гетерогенний полісуб' $є к т$, щзо здатний власним різноманіттям конструктів нівелювати складність та невизначеність ринкових та інноваційних прочесів. Умови ефективної взаємодї когнітивно гетерогенного полісуб'єкта $\epsilon$ прерогативою модератора со-творчості, який має бути орієнтований на підтримку високого рівня різноманіття суб'єктів - з одного боку, а з іншого - забезпечувати семантичну та комунікаиійну спряженість акторів для здійснення ефективних міжсуб 'єктних інтеракцій.

Ключові слова: полісуб'єкт, зборка, со-творчість, когнітивна складність, когнітивна гетерогенність, гетерархія, інноваційна иүінність

Рис. - 1, Табл. - 1, Літ. - 18. 
Постановка проблеми в загальному вигляді. У реальному секторі при управлінні інноваційними процесами, загострюється наступне науково-практичне протиріччя, 3 одного боку, в теорії (експліцитно) наголошується на необхідності виконання цілого ряду положень (соціальна відповідальність, сталий розвиток, співтворчість, партнерські взаємини зі споживачем і багато іншого), з іншого боку, на практиці (імпліцитно) ситуація характеризується використанням протилежних тенденцій (особливо це відноситься до вітчизняних суб'єктів господарювання). Подолання такого стану бачиться в використанні парадигм со-творчості та множинних джерел інновацій, 3 можливістю інтеграції всіх зацікавлених сторін, з метою активної адаптації підприємства до еволюційних тенденцій зовнішнього середовища.

Аналіз останніх досліджень і публікацій. Теоретико-методологічний базис колабораційного створення інновацій закладено у працях таких дослідників: Й. Бенклер, Г. Бхолла, П. Друкер, М. Кастельс, К. Лакхані, Ч. Лідбітер, К. Прахалад, В. Рамасвамі, Е. Роджерс, Д. Старк, Дж. Хау, Е. Хиппель, Г. Чесбро, Ф. Янсен. Однак в працях зазначених авторів, в переважній більшості випадків увага акцентується на різноманітних аспектах інноваційного менеджменту, фрагментарно відображуючи механізми зборки та взаємодії полісуб' єкту спільного створення інноваційних цінностей.

Мета статті - аналіз та обгрунтування теоретичних і емпіричних основ зборки полісуб'єкта, орієнтованого на співтворчість і розширення когнітивної гетерогенності суб'єктів інноваційного розвитку для активізації інноваційних процесів підприємства та підвищення релевантності створюваних інновацій.

Методи дослідження. Для досягнення мети дослідження використовувались такі загальнонаукові та спеціальні методи та прийоми: теоретичний аналіз та синтез, аналогія, а також методи систематизації та наукового узагальнення. Використовується методологія структурованого обзору 3 акцентом на когнітивну, поведінкову та управлінську сутність процесів спільного створення інноваційних цінностей в умовах зростаючої складності процесів інноваційної діяльності та невизначеності ринкового середовища.

Основний матеріал. Безальтернативність інтеграції інноваційних процесів суб'єкта господарювання та колективної творчості суб'єктів зовнішнього середовища визначена і продемонстрована на концептуальному рівні управління інноваціями на підприємстві. В цьому аспекті О. Богданов, розвиваючи ідеї загальної організаційної науки, першим представив організацію, як процес постійних перетворень, пов'язаних 3 безперервною зміною станів рівноваги. Збереження системи, на його думку, забезпечується активним використанням зовнішнього середовища, яке він визначав, як «сукупність тих зовнішніх активностей, які безпосередньо здійснюють на неї вплив» [1, c. 166]. Зовнішнє середовище представляється як одна з головних умов існування i розвитку підприємства, а також як джерело невизначеності, що забезпечує необхідну різноманітність його станів. Підприємство не просто взаємодіє із зовнішнім середовищем, але, будучи структурно пов'язаним 3 ним, адаптується до змін і еволюціонує разом з ним.

На думку Ч. Лідбітера, ідеї, що постійно циркулюють у вільному доступі, створюють підстави для творчості мільйонам винахідників i раціоналізаторів, які самоактуалізуються. Він прогнозує, що «у XX столітті нас визначало те, чим ми володіємо; в XXI столітті - то, як і чим ми ділимось з іншими» [2, с. 123]. Концепція спільної творчості дозволяє швидко аналізувати ідеї, користуючись великим набором точок зору, які циркулюють між згуртованим ядром спільноти і безліччю спостерігачів. На думку Дж. Хау: «... часто правильно організована суспільна праця виявляється більш 
результативною, ніж праця корпоративна» [3, с. 15]. Й. Бенклер стверджує, що суспільне створення інноваційних цінностей $є$ альтернативою традиційному корпоративному, який він визначає, як «співпраця між людьми, організованими без допомоги ринків або управлінської ієрархії» [4, с. 54]. Е. Хиппель 3 цього приводу зазначає, що організовані таким чином інноваційно-активні спільноти орієнтовані на виробництво затребуваних об'єктів, вони не продукують без видимої потреби [5]. У сучасній практиці створення інноваційних цінностей з'являються такі форми співтворчості, коли підприємство, 3 метою 3'ясування можливих сфер використання створених інновацій, передає їх споживачам, останні адаптують їх до практичних потреб, вносячи в них удосконалення різного ступеня складності, К. Ширкі визначив дану практику, як «даунсорсинг» [6]. В основі подібних форм співтворчості лежить фундаментальний принцип, про який писав Ф. Хайєк: «Цивілізація грунтується на факті, що ми отримуємо вигоду від знань, яких інші не мають. І одним із способів, яким цивілізація допомагає нам долати це обмеження на рівні індивідуального знання, $\epsilon$... не придбання нових знань, але використання знання, яке вже відомо i широко поширене серед людей» [7, с. 522]. На основі експериментального моделювання С. Пейдж прийшов до висновку, що «групи людей 3 різними здібностями і поглядами частіше пропонують більш креативні рішення, ніж групи високо компетентних фахівців з однаковими навичками та поглядами» [8, с. 241]. Групи, що складаються 3 людей, які думають по-різному, якщо вони правильно організовані, можуть перевершити групи дуже талановитих фахівців, які вирішують завдання за допомогою однакового набору інструментів.

Передумовою для третьої промислової революції, на думку Дж. Рифкіна, є перехід від ринків до мереж, що надає бізнесу іншу орієнтацію. Автор зазначає, що в новій економіці «антагоністичні взаємини між продавцями і покупцями замінюються на співпрацю між постачальниками і користувачами. На зміну особистій вигоді приходить загальний інтерес. Прагнення зберегти інформацію в своїй власності змінюється акцентом на відкритості і спільному володінні, яке засновано на довірі» [9, с. 164]. В інформаційній економіці дихотомія попиту та пропозиції не має сенсу в суспільстві, де інноваційні цінності створюються суб'єктами споживання, де при правильних умовах попит може створити власну пропозицію, відкриваючи нові великі джерела додаткових цінностей. Підприємства, що грунтуються на високому рівні участі суб'єктів зовнішнього середовища у власних інноваційних процесах, динамічно створюють релевантні інноваційні цінності. Однак на рівні механізму практичної реалізації сформульованих положень необхідно провести аналіз процесу зборки полісуб'єкта (команди), а також провести систематизацію чинників, які впливають на процес спільного створення інновацій, що забезпечують механізм організації ефективної взаємодії інноваційно-активних суб'єктів в рамках середовищ співтворчості.

Процес збірки полісуб'єкта спільного створення інноваційної цінності, включає в себе низку етапів (рис. 1):

1. Сукупність осіб, не пов'язаних спільною творчою діяльністю і таких, що не відображають один одного в якості суб'єктів, будемо розглядати як перший етап збірки полісуб'єкта, з умовною назвою - предсуб'єктний етап. Як зазначає I. Вачков, на предсуб'єктному етапі «людина не здатна сприйняти своє Я як цілісну систему і не здатна відобразити Іншого як суб'єкта, оскільки той хто відображає завжди відображає тільки іншу форму своєї власної природи» [10, с. 44]. На предсуб'єктному етапі збірки полісуб'єкта в отриманій сукупності осіб відсутні прояви цілісності. На даному етапі відбувається обмін інформацією між суб'єктами про свої компетенції, формування 
оціночних суджень один про одного. Вивчення проектного завдання, цілей проекту, власної ролі в полісуб'єкті, прийнятних способів спільної роботи.

2. Наступний етап збірки полісуб'єкта співтворчості, детермінується проявом суб'єктності, яка пов'язана з центрацією на собі і спрямована на використання інших у власних цілях. При цьому егоїстичність не виключає здатність розглядати своє Я як цілісність, як єдину систему. Разом з тим суб'єкти вже виділяють свою спільність як цілісність в протиставленні до «Вони» [11]. І. Вачков цю спільність пропонує назвати «атомарний колективний суб’єкт» [10, с. 44]. На даному етапі утворений тип спільності, в силу притаманних йому ознак, може бути віднесений до категорії колективного суб'єкта. Для цього етапу характерна ідейна і статусна конкуренція, яка супроводжується конструктивними і деструктивними конфліктами.

3. На даному етапі проявляється здатність до розгляду себе і спільності як цілісних систем. Але цей рівень ще не можна вважати полісуб'єктним, оскільки інші спільності розглядаються як позбавлені суб'єктної цілісності і відображаються як об'єкти. Ця особливість, яка характеризується як корпоративна закритість, дозволяє назвати виділену спільність «корпоративним суб'єктом» [10]. Для даного етапу характерно 3 боку суб'єкта управління: формування лояльності, розподіл обов'язків, поширення норм і цінностей; з боку керованих суб'єктів: співпраця, довіра, взаємодопомога.

4. Здатність до побудови не тільки внутрішньогрупових суб'єкт-суб'єктних відносин, але і міжгрупових, $є$ відмінною рисою наступного типу спільності. Полісуб'єктна взаємодія характеризується опорою на суб'єкт-суб'єктні відносини в ситуації створення зв'язків 3 іншими полісуб'єктами і спільнотами інших типів. Суб'єкти, що входять в цю спільність, здатні розглядати як суб'єктну цілісність і себе, i свою спільність, і інші спільності. Такий полісуб' єкт не є замкнутою системою, навпаки, можливості його розширення практично безмежні. Така спільність і називається полісуб'єктом.

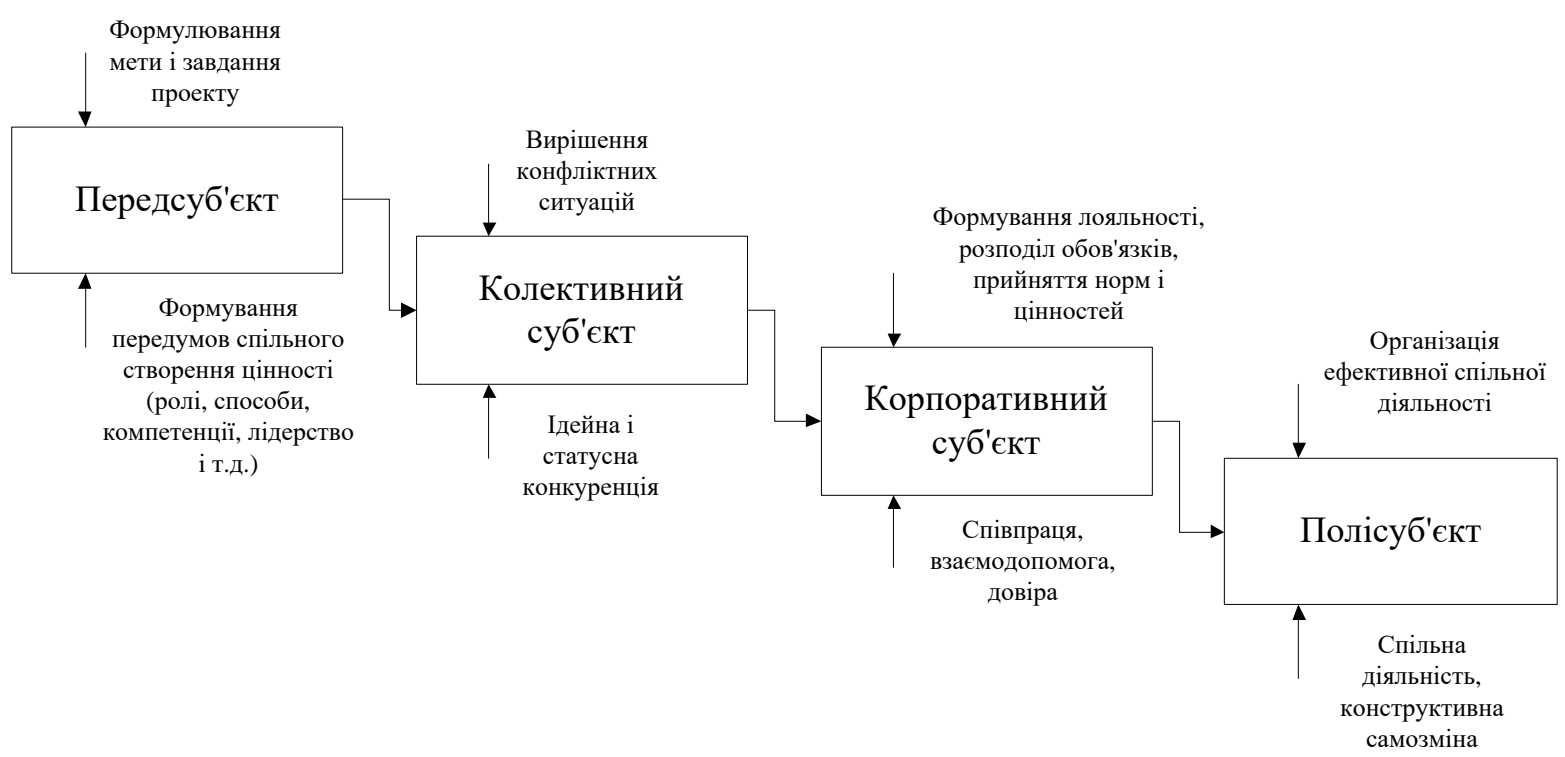

Рисунок 1. Основні етапи зборки полісуб'єкта спільного створення інноваційних цінностей (узагальнено за допомогою [10;12]) 
Процес ефективного функціонування полісуб'єктних середовищ передбачає врахування цілої низки факторів групової динаміки, що вимагає їх систематизації в аспекті процесів співтворчості. Умовно фактори ефективного функціонування полісуб'єктних середовищ можна розділити на чотири групи (рис. 2). Так, наприклад, фактори, пов'язані зі структурою групи, включають в себе наступні характеристики: кількісний і рольової склад полісуб'єкта; загальний час спільної роботи полісуб'єкта; якісне формулювання цілей i завдань; встановлені норми і цінності; модель комунікаційної мережі; лідерство і стилі керівництва. Більшість з перелічених факторів мають бути імплементовані на предсуб'єктному етапі зборки колаборації для забезпечення продуктивних передумов співтворчості.

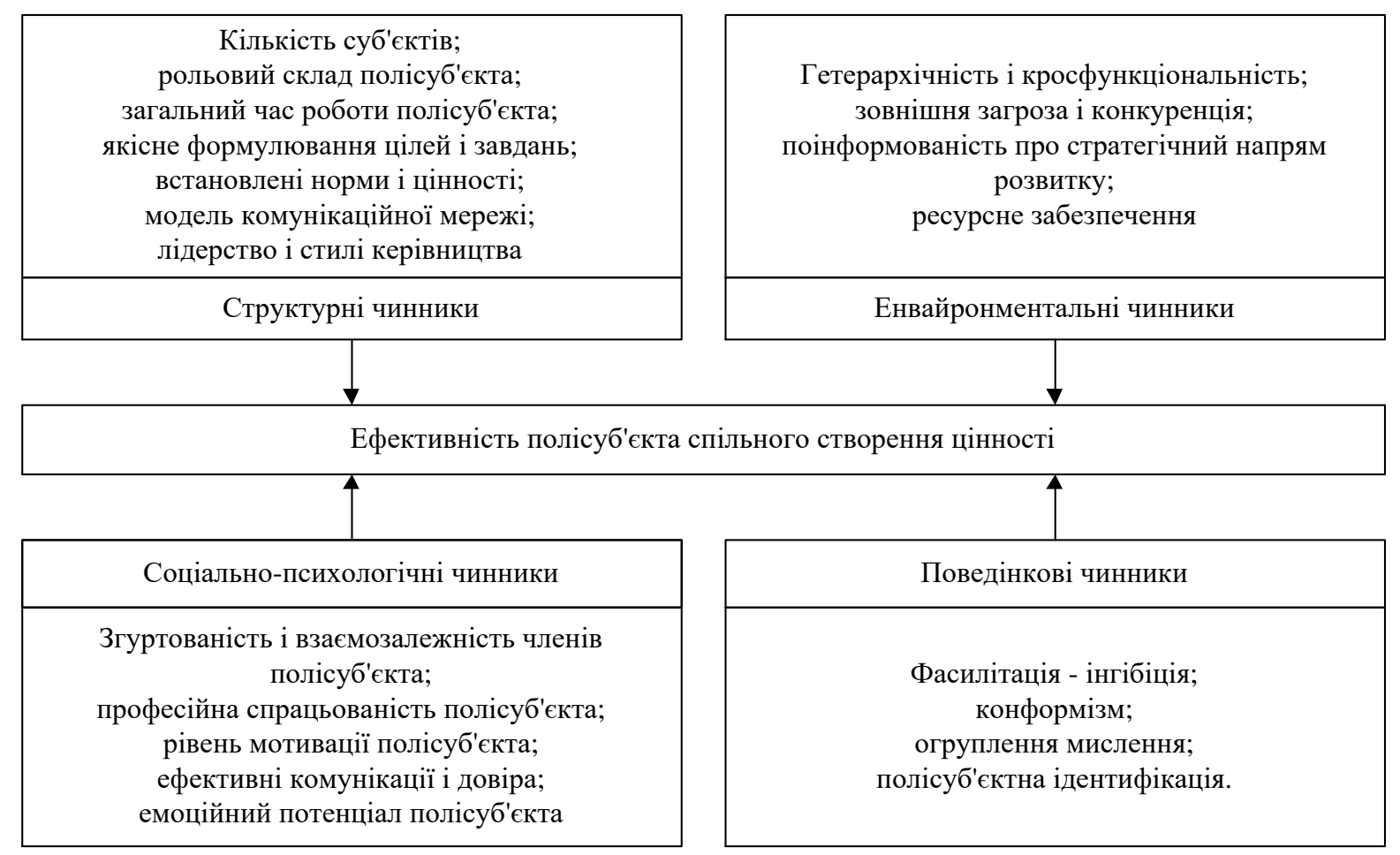

Рисунок 2. Фактори ефективного функціонування полісуб'єктних середовищ спільного створення інноваційних цінностей

Кількісний склад учасників. Класичний підхід до організації групової роботи будується на припущенні, що по мірі збільшення кількості членів, зменшується середній індивідуальний внесок в загальногрупову роботу; виникає ефект «соціальної ліні» [13]. Чим менше за чисельністю група, тим інтенсивніше в ній взаємодія, чим більше - тим частіше відносини формалізуються і перестають задовольняти учасників. Реальна взаємодія учасників регламентується числом Милера [14] та обумовлена обсягом свідомості та робочої пам'яті суб'єкта. Робоча група $37 \pm 2$ людини вважається оптимальною. Зазначена кількість інноваційно-активних суб'єктів, які здійснюють спільну діяльність, характерна для суб'єктів, які безпосередньо взаємодіють один 3 одним. У разі віртуальних взаємодій подібні обмеження можуть бути зняті, за рахунок перенесення основного навантаження, пов'язаного зі структурним спряженням i 
координацією суб'єктів на модераторів спільного створення інновацій. Подібні аналогії актуалізують питання про межі ефективності полісуб'єктного середовища, які досягаються за рахунок перевищення певної кількості інноваційно-активних суб'єктів. Так, наприклад, антрополог Р. Данбар припустив, що існує якась межа кількості людей, 3 якими суб'єкт може підтримувати постійні соціальні зв'язки. Вчений помітив залежність між рівнем розвитку нової кори великих півкуль головного мозку і розміром зграї у приматів. На підставі даних по 38 родам приматів він вивів математичну залежність між розвитком неокортексу i розміром зграї, i, грунтуючись на оцінці розвитку людського мозку i досягненнях антропології, запропонував оцінку оптимального розміру людської групи, яка знаходиться в діапазоні від 100 до 230 осіб, але найчастіше вважається рівною 150 [15]. В кінці 2012 року в Facebook було приблизно 1,06 млрд. користувачів і 150 млрд. зв'язків між друзями, тобто в середньому по 141 другові на користувача, що потрапляє в діапазон числа Данбара. Однак для конкретного підприємства база потенційних учасників спільного створення інновацій не повинна бути занадто великою.

Наступним елементом, що характеризує структуру полісуб'єктного середовища, $є$ iii рольовий склад. Ефективність групи може залежати від профілю команди і балансу ролей в ній. Склад групи повинен відповідати вимогам завдання, для виконання якого вона створена. Процес спільного створення інновацій дещо нівелює значимість даного параметра, тому що основне завдання фільтрації ідей покладено на модератора, а когнітивна гетерогенність суб'єктів є індикатором інноваційної активності полісуб'єкта.

Загальний час спільної роботи суб'єктів в рамках полісуб'єкта свідчить про стадії розвитку полісуб'єкта, його об'єктивної здатності ефективно працювати. Перш ніж настає період високої продуктивності робочої групи, йому передує кілька етапів збірки і формування полісуб'єкта. Зміна складу полісуб'єкта може відкинути його на більш ранню стадію розвитку, що вимагає повторного проведення процедури структурного спряження групи.

В рамках цілей і завдань, які стоять перед групою, слід виділити такі параметри, як важливість мети групової діяльності та розуміння методів і способів досягнення мети. Цілі повинні бути чіткими, сфокусованими і повинні створювати уявлення про методи роботи й завдання, які приведуть до результату. Слід враховувати специфіку вирішуваних завдань (ix взаємозв'язок i складність). При вирішенні складних нестандартних завдань ефективніше використовувати методи групового прийняття рішень. Для простих рутинних завдань упор повинен бути зроблений на стандартизацію та формалізацію процесу роботи.

Продуктивність полісуб'єкта спільного створення інновацій може визначатися тим, наскільки норми поведінки, прийняті в групі, націлені на досягнення високих результатів іiі роботи, а встановлені цінності в рамках полісуб'єкта сприяють формуванню інноваційної культури.

Модель комунікаційної мережі (централізована або децентралізована). Ефективність комунікаційних мереж залежить від тих завдань, які виконує група. Централізовані будуть ефективніші, якщо група виконує відносно прості завдання, тому що це дозволяє зробити менше помилок і швидше досягти мети. Якщо завдання ускладняється, то направлення всієї інформації через одну людину на центральній позиції забирає багато часу i не дає проявляти ініціативу іншим членам групи. Децентралізовані системи дають всім членам групи однакові можливості для участі в колаборації та контролі. 
Лідерство і стиль керівництва. Лідер (модератор) безпосередньо впливає на досягнення групових цілей, тому що на нього покладено функції з високим ступенем відповідальності: організація групи, координація їі дій, забезпечення зовнішніх зв'язків, прийняття рішень; регулювання міжособистісних відносин. Таким чином, спрямованість лідерства (конструктивна, деструктивна, нейтральна), як і стиль керівництва, має безпосередній вплив на ефективність групової роботи. Міра впливу лідера на групу є досить динамічною величиною: в залежності від ситуаційних параметрів вона зростає або знижується. Лідерство як той чи інший соціально-психологічний феномен керівництва в полісуб'єктному середовищі можна класифікувати як вираз групових інтересів, думок і настроїв, які враховує і генерує модератор, направляючи всю роботу на досягнення кінцевих результатів. Можуть бути три типи такого лідера - організатор, фахівець, інтелектуал, особливий тип лідерства виникає тоді, коли він стає реорганізатором (інноватором) [16].

Наступною інтегральною характеристикою ефективності функціонування полісуб'єктних середовищ є зовнішнє середовище. До факторів зовнішнього середовища, що впливають на результати діяльності групової роботи, відноситься організаційна структура. Робочу групу слід розглядати 3 урахуванням офіційної структури організації: чи співпадає група 3 формальним розподілом на відділи i підрозділи або в неї входять працівники з різних підрозділів. У сучасних динамічних організаціях, як правило, полісуб'єктне середовище має гетерархічну кросфункціональну природу (проектні групи, технологічні клуби, команди якості та досконалості). Дана ситуація пояснюється складністю ділових процесів в організації, що змушує керівництво використовувати міждисциплінарний підхід до створення інновацій, за рахунок залучення в групу фахівців різного профілю не тільки з різних структурних підрозділів, а й із зовнішнього середовища.

Існування загрози групі ззовні або конкуренція з іншою групою також впливають на ефективність групової роботи. Згуртованість і узгодженість дій групи посилюється в разі наявності зовнішньої загрози чи конкуренції з іншою аналогічною групою, в силу особливостей групової поведінки.

Високий вплив на функціонування полісуб'єктних середовищ має стратегія організації, до якої належить група. Стратегія розвитку організації визначає стратегію функціонування кожної конкретної групи, що входить до їі складу. Достатність або обмеженість ресурсів впливають на специфіку роботи всіх підрозділів організації (можуть виникати конфлікти з їх перерозподілу). Прийнята в організації система підбору персоналу визначає склад всієї організації та кожної групи окремо, а, відповідно, і їі потенціал. Системний підхід до мотивації передбачає врахування особливостей мотивації працівників на особистісному, груповому та організаційному рівнях.

Ще одна група чинників, які впливають на функціонування середовищ співтворчості, характеризує соціально-психологічний клімат в групі. Ступінь згуртованості і взаємозалежності членів групи визначає їх готовність і здатність ефективно взаємодіяти під час виконання завдання. Однак результативність та згуртованість мають тенденцію до позитивного зв'язку тільки в разі високої мотивації членів групи, i якщо прийняті в групі норми передбачають високий рівень продуктивності. Ця якість формується тільки в результаті накопиченого досвіду спільної роботи професіоналів і проявляється в нормах взаємоповаги, взаємної відповідальності, взаємовимогливості, де кожен має «вагу», доповнюючи своєю майстерністю інших працівників. Це особливо спостерігається в полісуб' єктних середовищах, якщо їх праця організована з точки зору швидкого вирішення у спільній діяльності всіх проблем, що 
виникають на «стиках» різнорідних робіт. Ще одна характеристика, що впливає на синергію полісуб'єктних середовищ, є іiі морально-психологічна згуртованість, тобто властивість синергії, яка проявляється в єдності ціннісно-цільових орієнтирів всіх суб'єктів, інтереси яких виявляються загальними. Ця якість формується на основі спільності уявлень про самих себе як групу, яка може виконувати надзавдання. На цій соціально-ціннісній основі формуються такі норми поведінки, як взаємодопомога, взаємопідтримка, взаємовиручка [16, с. 121]. Єдність ціннісно-цільових орієнтацій - це інтегральний показник внутрішньогрупових зв'язків, що трансформує механістичну групу в органічну команду. Врахування і задоволення потреб членів команди підвищують мотивацію, що орієнтує на максимальну результативність і зниження витрат на управління. Внутрішньогрупова підтримка забезпечує кращу результативність, тому що ефективні комунікації і довірчі відносини дозволяють знизити витрати взаємодії i забезпечують вирішення поставлених завдань. Емоційний потенціал полісуб'єкта визначається загальним емоційним станом спільноти в цілому і окремих суб'єктів і визначається минулими успіхами і невдачами спільної діяльності; дисципліною; взаємовідносинами між суб'єктами і т.д. Інтенсивність прояву і часова протяжність емоційних станів визначаються значущими для полісуб'єкта умовами і подіями їхньої спільної діяльності.

У наступну групу віднесемо поведінкові чинники, пов'язані з різними груповими феноменами і ефектами. Для прояву ефекту соціальної фасилітації (вплив оточуючих на поведінку членів групи; зворотний - ефект інгібіції) необхідно, щоб структура діяльності була досить алгоритмізована, а завдання - простими. При вирішенні складних завдань, де ніхто не знає алгоритм рішення, реакція на присутність інших людей, незайнятих вирішенням цього ж завдання, ускладнює розумові операції і підвищує ймовірність неправильного рішення (ефект інгібіції).

У груповій взаємодії ефект конформізму відіграє істотну роль, оскільки є одним 3 механізмів прийняття групового рішення. 3 одного боку, він $є$ фактором групової згуртованості та інтеграції, з іншого - в крайніх проявах зводить ефективність групи до здібностей однієї особи (лідера). У тому випадку, коли члени групи стикаються 3 загрозою розбіжностей, суперечок і конфліктів, вони намагаються зменшити груповий когнітивний дисонанс і усунути виниклі при цьому негативні почуття, намагаючись знайти рішення, яке влаштовує всіх, навіть якщо це рішення не буде об'єктивним i розумним з точки зору кожного окремого члена групи. Відсутність критики призводить до того, що прийняті рішення переслідують лише одну мету - збереження групи. Даний феномен отримав назву ефект «огруплення мислення» [17]. Полісуб' єктна ідентифікація характеризує ототожнення суб'єкта з узагальненим образом члена полісуб'єкта, за рахунок якого відбувається прийняття, часто некритичне цілей, цінностей та рішень полісуб'єкта.

Крім перерахованих факторів ефективності функціонування полісуб'єктних середовищ спільного створення інноваційних цінності, в когнітивних науках накопичений значний обсяг знань щодо механізмів перцепції та інтеракції, які $\epsilon$ ключовими при реалізації колабораційних інноваційних процесів, орієнтованих на створення інновацій. Підставою для створення конкурентоспроможної інноваційної цінності $є$ ступінь когнітивної складності суб'єктів, що входять в полісуб'єктне середовище, формуючи тим самим необхідний рівень когнітивної гетерогенності, здатний адекватно відображати складність зовнішнього (ринкового) середовища. Це передбачає максимізацію розглянутих альтернатив створюваної інновації та іiі властивостей, що знижує рівень невизначеності щодо створюваного продукту і підвищує 
ймовірність створення релевантної інновації, в результаті врахування широкого спектра критеріїв споживчого оцінювання в створюваному об'єкті.

Тонке підстроювання через здатність розрізнення різноманіття властивостей об’єкта вимагає реалізації полісуб'єктом рефлексивного підходу, який передбачає здатність стати в позицію споживача, тобто ціннісної децентрації, на противагу лінійній парадигмі інноваційного розвитку, що стоїть на позиціях аксіоцентрізму (який вважає підприємство основним джерелом інноваційних цінностей). Крім цього, тонке підстроювання за допомогою когнітивної гетерогенності полісуб'єкта передбачає: спроможність виділяти в створюваному об'єкті істотні і другорядні властивості і характеристики; спроможність до амбівалентного сприйняття об'єкта, при якому суб'єкт може бачити одночасно як позитивні, так і негативні характеристики (ГМО, мікрохвильові печі, мобільний зв'язок і т.д.); спроможність встановлювати схожості та відмінності між одними і тими ж об'єктами за різними підставами, утворюючи різні способи їх групування; гнучкість мислення, яка полягає в готовності змінити свої уявлення про об'єкт в зв'язку з надходженням нової інформації на противагу ригідності. Одним 3 психологічних механізмів, за допомогою якого когнітивна складність може сприяти інноваційному мисленню, є механізм об'єктного розрізнення. Передбачається наявність негативного зв'язку між високою когнітивної складністю суб'єкта і величиною розрізнення об'єктів між собою. Дану залежність можна пояснити в термінах вимірювань. Чим більше властивостей суб'єкт використовує для характеристики об’єктивної цінності, тим менше його опис буде збігатися з іншими об'єктами. Для суб'єктів з низькою когнітивною складністю характерна тенденція бачити більше схожості між різними об'єктами, тому що при їх оцінці суб'єктом використовується обмежена кількість конструктів.

Відмінності між суб'єктами 3 високою і низькою когнітивною складністю стосуються не тільки кількісних, а й якісних характеристик розрізнення об'єктів. Суб'єкти 3 високою когнітивною складністю виробляють більше конструктів, що стосуються об'єктних особливостей, в той час як суб'єкти 3 низькою когнітивною складністю воліють називати титульні властивості i характеристики, нав'язуванні виробником. Це обумовлює різну концептуалізацію об'єктних цінностей суб'єктами, що залежить від притаманного когнітивного стилю «складний - простий».

Інтенсивність НТП ускладнила процеси розрізнення для більшості суб'єктів споживання, так як збільшення кількості альтернатив об'єктних цінностей в рамках однієї асортиментної групи, з одного боку, і відсутність адекватної можливості зіставити об’єкти (час, інтелект, інформація та ін.), з іншого, робить практично неможливим оптимальний вибір. Крім того, для суб'єктів з низькою когнітивною складністю характерна «кластерна оцінка», яка полягає в тому, що, виявивши в об'єкті негативну властивість, вони приписують йому й інші недоліки. Для полісуб'єктних середовищ спільного створення інновацій особливий інтерес представляють інноваційно-активні суб'єкти з високою когнітивною складністю, що характеризуються амбівалентним сприйняттям (в порівнянні 3 унівалентним у суб'єктів 3 низькою когнітивною складністю), що свідчить про їхню здатність бачити в об'єктах позитивні та негативні властивості одночасно. Крім цього, когнітивно складні суб'єкти більш критичні щодо недоліків об'єкта, це дозволяє їм паралельно вибудовувати можливості для вдосконалення, що $є$ передумовою для формування активної інноваційної позиції суб'єкта. Проведена систематизація факторів ефективної полісуб'єктної колаборації може бути представлена у вигляді складових інтегрального показника якості середовища співтворчості (табл. 1) [18]. 
Таблиця 1. Показники якості середовища співтворчості

\begin{tabular}{|c|c|c|}
\hline & Показники & Характеристика показника \\
\hline \multirow{8}{*}{ 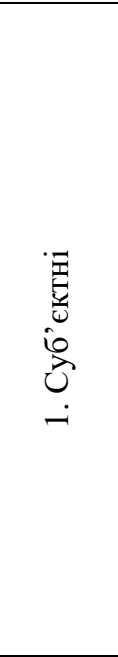 } & $\begin{array}{l}\text { 1.1. Ступень когнітивної складності } \\
\text { суб'єктів співтворчості }\end{array}$ & $\begin{array}{l}\text { Середній показник наявних когнітивних конструктів } \\
\text { суб'єктів співтворчості }\end{array}$ \\
\hline & $\begin{array}{l}\text { 1.2. Ступінь когнітивної } \\
\text { гетерогенності суб'єктів } \\
\text { співтворчості }\end{array}$ & $\begin{array}{l}\text { Різноманітність суб’єктів, що представляють якісно } \\
\text { різні види діяльності }\end{array}$ \\
\hline & $\begin{array}{l}\text { 1.3. Якість підготовки суб’єктів } \\
\text { співтворчості }\end{array}$ & Кількість суб'єктів з вищою освітою \\
\hline & $\begin{array}{l}\text { 1.4. Кількість суб’єктів з науковим } \\
\text { ступенем }\end{array}$ & $\begin{array}{l}\text { Кількість суб'єктів, які мають ступінь кандидата або } \\
\text { доктора наук }\end{array}$ \\
\hline & 1.5. Кількість суб’єктів інженерії & Кількість суб’єктів з вищою технічною освітою \\
\hline & $\begin{array}{l}\text { 1.6. Рівень задоволення експектацій } \\
\text { суб'єктів співтворчості }\end{array}$ & $\begin{array}{l}\text { Ступінь } \quad \text { відповідності } \\
\text { полісуб'єктного середовища мотиваційніиій сфері суб'єкта }\end{array}$ \\
\hline & $\begin{array}{l}\text { 1.7. Рівень відповідності } \\
\text { аксіологічних норм середовища } \\
\text { цінностям суб'єкта }\end{array}$ & $\begin{array}{l}\text { Ступінь консонансу колективних та індивідуальних } \\
\text { цінностей }\end{array}$ \\
\hline & 1.8. Рівень автономності полісуб’єкта & Можливість полісуб’єкта самостійно визначати власні цілі \\
\hline \multirow{3}{*}{ ¿ 兽 } & 2.1. Семантична інтероперабельність & $\begin{array}{l}\text { Здатність узгодженої колаборації, на основі єдиної } \\
\text { інтерпретації інформації, що використовується }\end{array}$ \\
\hline & 2.2. Рефлексивна інтероперабельність & $\begin{array}{lccc}\text { Здатність узгодженої } & \text { колаборації, } & \text { на } & \text { основі } \\
\text { конгруентного відображення образів інших суб'єктів }\end{array}$ \\
\hline & 2.3. Транспарентність процесу & Рівень відкритості та доступності необхідної інформації \\
\hline \multirow{7}{*}{ 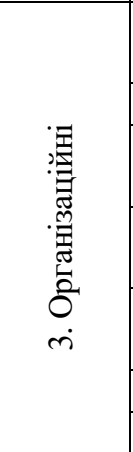 } & 3.1. Рівень координації колаборації & $\begin{array}{l}\text { Ступінь забезпечення взаємозв'язку та структурного } \\
\text { спряження діяльності суб'єктів співтворчості }\end{array}$ \\
\hline & 3.2. Кількість суб’єктів колаборації & Чисельність суб’єктів співтворчості \\
\hline & $\begin{array}{l}\text { 3.3. Рівень полісуб'єктної } \\
\text { толерантності до інноваційних ідей }\end{array}$ & $\begin{array}{l}\text { Ступінь терпимості полісуб’єкту до іншого світогляду } \\
\text { акторів }\end{array}$ \\
\hline & $\begin{array}{l}\text { 3.4. Рівень стабільності складу } \\
\text { суб'єктів співтворчості }\end{array}$ & Ступінь сталості полісуб'єктного складу \\
\hline & $\begin{array}{l}\text { 3.5. Кількість ідей доведених до рівня } \\
\text { концепту }\end{array}$ & Практичний результат співтворчості (основний) \\
\hline & 3.6. Кількість отриманих патентів & Науково-практичний результат співтворчості (побічний) \\
\hline & 3.7. Кількість зроблених публікацій & Науковий результат співтворчості (побічний) \\
\hline
\end{tabular}

Висновки. Таким чином, суб'єкти з високою когнітивною складністю володіють найбільшими передумовами до інноваційного мислення, оскільки вони демонструють спроможність щодо децентрації при оцінці об'єктних цінностей, спроможність до концептуалізації різних властивостей об'єкта в цілісний образ, гнучкість суджень. Чим ширше інтерпретаційні можливості має суб'єкт (полісуб'єкт), тим вище ймовірність створення релевантної інноваційної цінності. Полісуб'єктні середовища, здатні створювати релевантні цінності в тій мірі, в якій вони здатні відтворювати у властивостях інновації основний спектр споживчих конструктів. Щоб рефлексивно впливати на споживача, необхідно розуміти систему його сприйняття і мислення, а для цього слід концептуалізувати систему його когнітивних конструктів. Когнітивно складному суб'єкту легше відтворити просту систему переваг і очікувань, ніж навпаки, тому його інтерпретаційні можливості щодо об'єктних цінностей є більш високими. Тому створення і підтримка умов ефективної взаємодії когнітивно гетерогенного полісуб'єкта є прерогативою модератора со-творчості, який має бути орієнтований на підтримку високого рівня різноманіття суб'єктів - 3 одного боку, а 3 іншого забезпечувати семантичну та комунікаційну спряженість акторів для здійснення ефективних міжсуб'єктних інтеракцій. 


\section{СПИСОК ВИКОРИСТАНИХ ДЖЕРЕЛ}

1. Богданов, А. А. (1989).Тектология : Всеобщая организационная наука. В 2-х кн. : Кн. 1. - М. : Экономика. -304 с.

2. Лидбитер, Ч. (2009). Мы - думаем : Массовые инновации, не массовое производство. - Пер. с англ. - М. : Аквамариновая книга. - 264 с.

3. Хау, Дж. (2012). Краудсорсинг : Коллективный разум как инструмент развития бизнеса. - Пер. с англ. - М. : Альпина Паблишер. - 288 с.

4. Benkler, Y. (2006). The Wealth of Networks : How Social Production Transforms Markets and Freedom. - New Haven : Yale University Press. - 515 p.

5. Hippel, E. (2005). Democratizing Innovation. - Cambridge : MIT Press. -220 p.

6. Shirky, C. (2010). Cognitive Surplus : Creativity and Generosity in a connected age / C. Shirky. - London : Penguin books, 2010. - 242 p.

7. Hayek, F. A. (1945). The Use of Knowledge in Society. American Economic Review. - № 4: 519-530.

8. Page, S. E. (2007). The Difference : How the Power of Diversity Creates Better Groups, Firms, Schools, and Societies. - Princeton : Princeton University Press. -320 p.

9. Рифкин, Дж. (2014). Третья промышленная революция. Как горизонтальные взаимодействия меняют энергетику, экономику и мир в целом. - Пер. с англ. - М. : Альпина нон-фикшн. -410 с.

10. Вачков, И. В. (2014). Полисубъектное взаимодействие в образовательной среде. Психология. № 2: 36-50.

11. Белбин, М. Р. (2003). Типы ролей в командах менеджеровПер. с англ. - М. : HIPPO. $-315 \mathrm{c}$.

12. Лепский, В. Е. (2012). Организация саморазвивающихся инновационных сред. М. : «Когито-Центр». - 192 с.

13. Karau, S. J.; Williams, K. D. (1993). «Social loafing: A meta-analytic review and theoretical integration». Journal of Personality and Social Psychology. 65 (4): 681-706. doi:10.1037/0022-3514.65.4.681.

14. Miller, G. A. (1956). The Magical Number Seven, Plus or Minus Two : Some Limits on our Capacity for Processing Information. The Psychological Review. 63: 81-97.

15. Данбар, Р. (2012). Лабиринт случайных связей. - Пер. с англ. - М. : Изд. «Ломоносов». -288 с.

16. Красовский, Ю.Д. (2003). Организационное поведение. - М.: ЮНИТИ-ДАНА. $511 \mathrm{c}$.

17. Irving, J. (1971). Groupthink : The Desperate Drive for Consensus at Any Cost. Psychology Today. № 2: 24-32.

18. Безгин, К.С. (2015). Управление процессом создания ценности на предприятии: полисубъектность и коллаборация: монография. - Харьков: «НТМТ». - 288 с.

Безгин К.С., Ушкалев В.В.

СБОРКА ПОЛИСУБЪЕКТА СОВМЕСТНОГО СОЗДАНИЯ ИННОВАЦИОННЫХ ЦЕННОСТЕЙ

Фундаментальной предпосылкой гармонизачии сочиильно-экономических процессов является разработка и имплементация внутренне согласованной системы взглядов, способных настроить ответственную инновационную деятельность, реализующуюся на принципах устойчивого развития. Достижения когнитивных наук и постнекласичного менеджмента свидетельствуют, что существенный вклад в формирование новой системы взглядов на инноватику может сделать парадигма со-творчества. Цель 
статьи - анализ и обоснование теоретических и эмпирических основ сборки полисубъекта, ориентированного на сотворчество и расширение когнитивной гетерогенности субъектов инновационного развития для активизации инновационных процессов предприятия и повыщения релевантности создаваемых инноваций. В статье рассмотрены основные этапы сборки полисубъекта совместного создания инновационных иееностей с их наполнением в реперных точках индикативными признаками групповой динамики, фиксируюшими качественные изменения в сообществе. Представлена констелляичя фактор эффективного функиионирования полисубъектных сред совместного создания инновационных иенностей, которые локализованы по основным этапам сборки. В работе показано, что полисубъект совместного создания инноваций, способен генерировать релевантные иенности в той мере, в какой он способен воспроизводить в свойствах создаваемых объектов основной спектр потребительских конструктов. Предпосылкой релевантных результатов инновационной деятельности является со-творчество субъектов с высокой когнитивной сложностью, которые в своей совокупности образуют когнитивно гетерогенный полисубъект, способный собственным многообразием конструктов нивелировать сложность и неопределенность рыночных и инновационных прочессов. Условия эффективного взаимодействия когнитивно гетерогенного полисубъекта являются прерогативой модератора со-творчества, который должен быть ориентирован на поддержание высокого уровня разнообразия субъектов - c одной стороны, а с другой - обеспечивать семантическую и коммуникационную сопряженность акторов для осуществления эффективных межсубъектных интеракций.

Ключевые слова: полисубъект, сборка, со-творчество, когнитивная сложность, когнитивная гетерогенность, гетерархия, инновационная цуенность

\section{K. Bezgin, V. Ushkalev ASSEMBLING A POLY-SUBJECT FOR JOINT CREATION OF INNOVATIVE VALUES}

The fundamental prerequisite for the harmonization of socio-economic processes is the development and implementation of an internally coordinated system of views that can set up responsible innovation activities that are implemented on the principles of sustainable development. Achievements in cognitive sciences and postnonclassical management indicate that the paradigm of co-creativity can make a significant contribution to the formation of a new system of views on innovation. The purpose of the article is to analyze and substantiate the theoretical and empirical foundations of the assembly of a polysubject focused on co-creation and expanding the cognitive heterogeneity of the subjects of innovative development to activate the innovative processes of the enterprise and increase the relevance of the created innovations. The article examines the main stages of the assembly of the polysubject of the joint creation of innovative values with their filling in the reference points with indicative signs of group dynamics, fixing the qualitative changes in the community. The constellation of the factor of the effective functioning of polysubject environments for the joint creation of innovative values, which are localized according to the main stages of assembly, is presented. The paper shows that the polysubject of cocreation of innovations is able to generate relevant values to the extent that it is able to reproduce the main spectrum of consumer constructs in the properties of the objects being created. A prerequisite for relevant results of innovation activity is the co-creation of subjects with high cognitive complexity, which together form a cognitively heterogeneous poly-subject, capable of leveling the complexity and uncertainty of market and innovation processes with its own variety of constructs. The conditions for effective interaction of a cognitively heterogeneous polysubject is the prerogative of the moderator of co-creativity, who should be focused on maintaining a high level of diversity of subjects - on the one hand, and on the other, to provide semantic and communication connectivity of actors for effective intersubjective interactions.

Key words: polysubject, assembly, co-creation, cognitive complexity, cognitive heterogeneity, heterarchy, innovative value 